\title{
Lead(II) complexes of lateral macrobicyclic receptors that incorporate a crown moiety and a pyridine head unit ${ }^{i}$
}

David Esteban-Gómez, Teresa Enríquez-Pérez, Raquel Ferreirós-Martínez, Marta Mato-Iglesias,

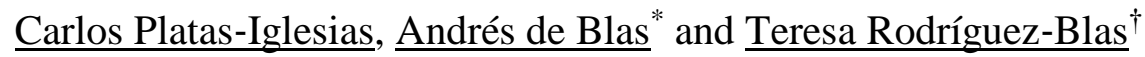

Departamento de Química Fundamental, Facultade de Ciencias, Universidade da Coruña, Rúa da Fraga 10, 15008

A Coruña, Spain

European Journal of Inorganic Chemistry, volume 2010, issue 31, pages 5027-5034, November 2010

Received 09 June 2010, version of record online 21 September 2010, issue online 22 October 2010

This is the peer reviewed version of the following article:

Esteban-Gómez, D., Enríquez-Pérez, T., Ferreirós-Martínez, R., Mato-Iglesias, M., Platas-Iglesias, C., de Blas, A. and Rodríguez-Blas, T. (2010), Lead(II) Complexes of Lateral Macrobicyclic Receptors That Incorporate a Crown Moiety and a Pyridine Head Unit. Eur. J. Inorg. Chem., 2010: 5027-5034

which has been published in final form at https://doi.org/10.1002/ejic.201000642. This article may be used for non-commercial purposes in accordance with Wiley Terms and Conditions for Use of Self-Archived Versions.

\begin{abstract}
The coordinative properties towards lead(II) of two lateral macrobicyclic receptors that incorporate either a 1,10-diaza-[15]crown-5 $\left(\mathbf{L}^{7}\right)$ or a 4,13-diaza-[18]crown-6 $\left(\mathbf{L}^{\mathbf{8}}\right)$ fragment are reported. Spectrophotometric titrations performed in acetonitrile solution indicate only the formation of mononuclear complexes in solution. The X-ray crystal structures of the two receptors show that the conformation adopted by the ligand is imposed by the presence of intramolecular hydrogen-bonding interactions that involve the secondary amine groups and the pivotal nitrogen atoms. The solid-state structure of $\left[\mathrm{Pb}\left(\mathbf{L}^{7}\right)(\mathrm{NCS})\right](\mathrm{SCN}) \cdot 0.5 \mathrm{H}_{2} \mathrm{O}$ shows that the metal ion is asymmetrically coordinated inside the macrobicyclic cavity. $\mathrm{The}^{\mathrm{Pb}}{ }^{\mathrm{II}}$ ion is coordinated to the nitrogen atom of the pyridine unit, the two secondary amine atoms, two oxygen atoms of the crown moiety, and a nitrogen atom of an isothiocyanate group. The distances between the $\mathrm{Pb}^{\mathrm{II}}$ ion and the two pivotal nitrogen atoms as well as one of the oxygen atoms of the crown moiety are too long (>2.92 $\AA$ ) to be considered unequivocal bonds, and should be regarded only as weak interactions. The protonation constants of $\mathbf{L}^{7}$ and $\mathbf{L}^{\mathbf{8}}$ as well as the stability constants of their $\mathrm{Pb}^{\mathrm{II}}$ complexes were investigated by using potentiometric titrations in $95 \%$ methanol $\left(I=0.1 \mathrm{M}, n \mathrm{Bu}_{4} \mathrm{NClO}_{4}, 25{ }^{\circ} \mathrm{C}\right)$. The two receptors undergo two protonation processes in the $\mathrm{pH}$ range investigated $(2.0<\mathrm{pH}<12.0)$, which correspond to the protonation of the nitrogen atoms of the oxa-aza moiety. The $\log K_{\mathrm{PbL}}$ value obtained for $\mathbf{L}^{7}$ [9.906(1)] is approximately 1.1 $\log K$ units higher than the one determined for $\mathbf{L}^{\mathbf{8}}$ [8.75(1)].
\end{abstract}

Keywords: macrocycles; N,O ligands; lead; crown compounds; cryptands

\footnotetext{
*andres.blas@udc.es

† teresa.rodriguez.blas@udc.es
} 


\section{Introduction}

The interest in the coordination chemistry of lead(II) is related to its inherent toxicity and health effects and to the widespread industrial uses of its compounds. ${ }^{1,2}$ Lead poisoning particularly affects young children, who can absorb up to $50 \%$ of ingested lead. ${ }^{3}$ Once ingested through the gastrointestinal tract, lead accumulates in soft tissues, including vital organs such as the kidneys, liver, or brain, where it is bound to thiol and phosphate groups in proteins, nucleic acids, and cell membranes, ${ }^{4,5}$ ultimately resulting in severe neurological and/or hematological effects. ${ }^{6,7}$ Among the different platforms used for lead(II) complexation, macrocyclic receptors such as crown ethers and related systems, ${ }^{8}$ calixarenes, ${ }^{9}$ or cryptands ${ }^{10}$ play an essential role. These receptors possess a high level of preorganization that often results in superior selectivities of their complexes with metal ions in comparison to those of acyclic ligands. ${ }^{11}$

Lateral macrobicycles are dissymmetrical molecules that are structurally based on the combination of two different binding subunits, a chelating one and a macrocyclic one. ${ }^{12}$ Considering the peculiar structural features shown by lateral macrobicycles, one could anticipate that this type of macropolycyclic architectures offers a range of interesting and potentially useful molecular recognition properties, as they offer the advantage of being preorganized and therefore capable of profiting from the thermodynamic macrobicyclic effect. Moreover, they contain convergent binding groups that can be especially designed to match the functionality of the guest molecule. It has been shown that lateral macrobicycles behave as very versatile receptors that can be used as platforms to obtain mono- ${ }^{13-16}$ and bimetallic ${ }^{17}$ complexes with many different aims (i.e., to induce processes of "push-pull" dimetallic substrate activation) ${ }^{18}$ and as receptors for organic molecules, ${ }^{19}$ anions, ${ }^{20}$ or contact-ion pairs. ${ }^{21,22}$
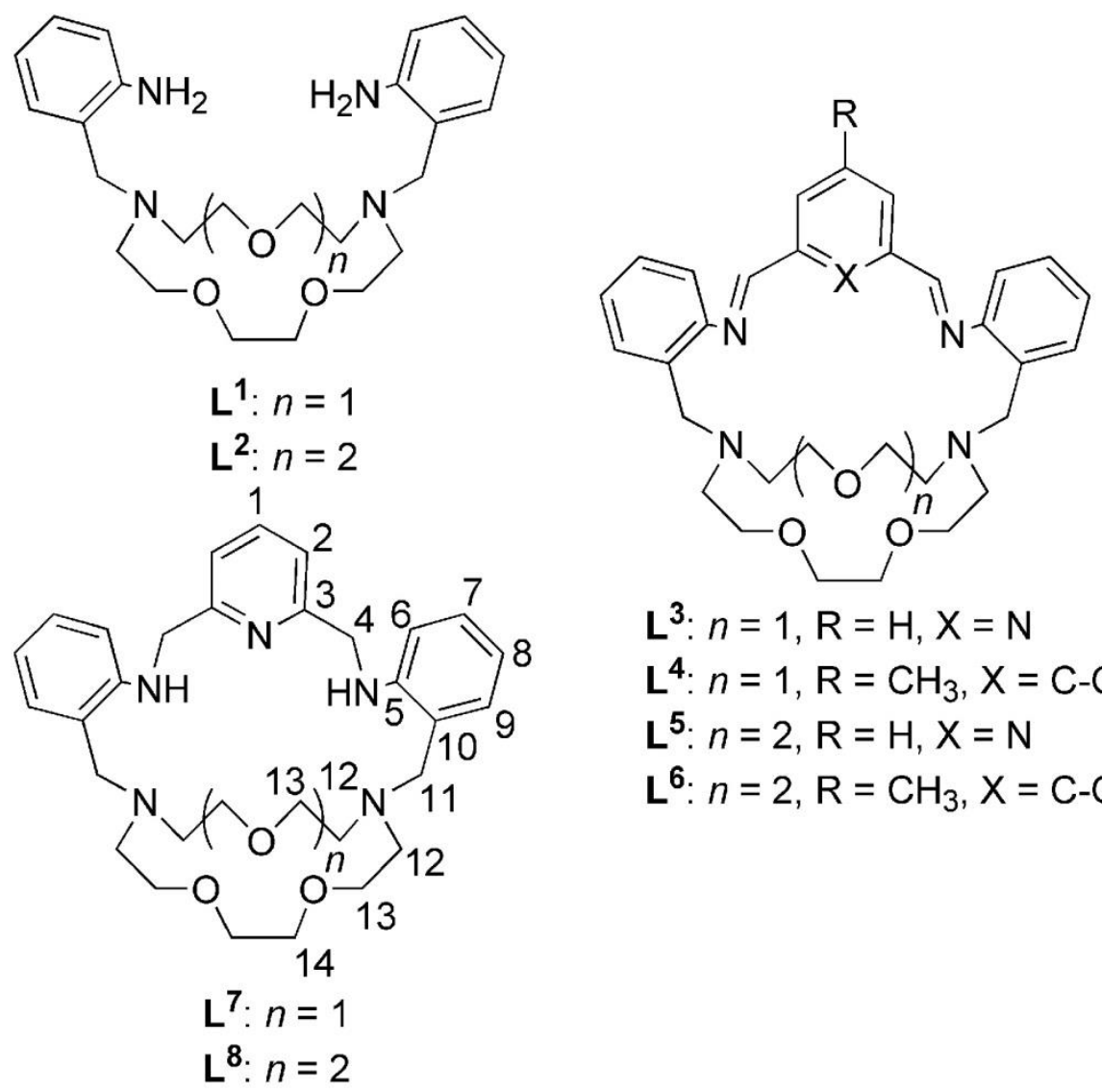

$$
\begin{aligned}
& \mathbf{L}^{3}: n=1, \mathrm{R}=\mathrm{H}, \mathrm{X}=\mathrm{N} \\
& \mathbf{L}^{4}: n=1, \mathrm{R}=\mathrm{CH}_{3}, \mathrm{X}=\mathrm{C}-\mathrm{OH} \\
& \mathbf{L}^{\mathbf{5}}: n=2, \mathrm{R}=\mathrm{H}, \mathrm{X}=\mathrm{N} \\
& \mathbf{L}^{6}: n=2, \mathrm{R}=\mathrm{CH}_{3}, \mathrm{X}=\mathrm{C}-\mathrm{OH}
\end{aligned}
$$

Scheme 1. Receptors discussed in the present work. 
We are interested in the relation between structure and stability of lead(II) complexes with macrocyclic ligands derived from crown ether platforms, as well as in the role of the lone-pair activity of $\mathrm{Pb}^{\mathrm{II}}$ in these kind of compounds. ${ }^{23,24}$ In previous works, we have carried out studies to asses the different complexation capabilities towardslead(II) of the bibracchial lariat ethers $\mathbf{L}^{116,25}$ and $\mathbf{L}^{214}$ and the related Schiff base lateral macrobicycles $\mathbf{L}^{3},{ }^{16,24} \mathbf{L}^{\mathbf{4}},{ }^{26} \mathbf{L}^{5}{ }^{15}$ and $\mathbf{L}^{625}$ (Scheme 1). These macrobicyclic receptors contain two different binding units: a rigid and unsaturated $\mathrm{N}_{2} \mathrm{X}$ set $(\mathrm{X}: \mathrm{N}, \mathrm{O})$ and a flexible and cyclic $\mathrm{N}_{2} \mathrm{O}_{n}(n=3$ or 4) set linked by aromatic bridges. As a continuation of these works, in this paper we report the complexation properties of lateral macrobicycles $\mathbf{L}^{7}$ and $\mathbf{L}^{8}$ toward $\mathrm{Pb}^{\text {II }}$. These receptors (Scheme $\mathbf{1}$ ) are expected to be more flexible than the parent Schiff base macrobicycles $\mathbf{L}^{3}$ and $\mathbf{L}^{5}$, which could result in a better fit of the coordinative requirements of the metal ion. We have selected the poorly coordinating perchlorate and the strongly coordinating thiocyanate groups as the anions of the metal salt, which allows us to study the effect that the different nature of the counterion may have on the metal coordination environment. The X-ray crystal structures of the two receptors as well as that of a $\mathrm{Pb}^{\mathrm{II}}$ complex with the receptor $\mathbf{L}^{7}$ have been obtained. The structure of the complexes in acetonitrile has been investigated by means of ${ }^{1} \mathrm{H}$ and ${ }^{13} \mathrm{C}$ NMR spectroscopy. Finally, the thermodynamic stability of the complexes in $\mathrm{MeOH} / \mathrm{H}_{2} \mathrm{O}(95: 5, v: v)$ mixtures has been investigated by using potentiometric titrations.

\section{Results and discussion}

\section{Synthesis and characterization of the complexes}

The macrobicyclic receptors $\mathbf{L}^{7}$ and $\mathbf{L}^{\mathbf{8}}$ were prepared by reduction of the corresponding $\mathrm{Pb}^{\mathrm{II}}$ perchlorate complexes of the Schiff base macrobicyclic precursors $\mathbf{L}^{3}$ and $\mathbf{L}^{5}$ (Scheme 1) with sodium borohydride. ${ }^{27}$ Reaction of $\mathbf{L}^{7}$ or $\mathbf{L}^{8}$ with of lead(II) salts (perchlorate or thiocyanate; 1 equiv.) in absolute ethanol gives complexes $\left[\mathrm{Pb}\left(\mathbf{L}^{7}\right)\right](\mathrm{SCN})_{2}(\mathbf{1}),\left[\mathrm{Pb}\left(\mathbf{L}^{7}\right)\right]\left(\mathrm{ClO}_{4}\right)_{2} \cdot \mathrm{MeOH}(\mathbf{2}),\left[\mathrm{Pb}\left(\mathbf{L}^{\mathbf{8}}\right)\right](\mathrm{SCN})_{2} \cdot \mathrm{H}_{2} \mathrm{O}(\mathbf{3})$, and $\left[\mathrm{Pb}\left(\mathbf{L}^{\mathbf{8}}\right)\right]\left(\mathrm{ClO}_{4}\right)_{2} \cdot \mathrm{H}_{2} \mathrm{O}(\mathbf{4})$ in good yields $(79-87 \%)$. The IR spectra (KBr disks) of $\mathbf{2}$ and $\mathbf{4}$ display bands that correspond to the $v_{\text {as }}(\mathrm{ClO})$ stretching and $\delta_{\text {as }}(\mathrm{OClO})$ bending modes of the perchlorate groups without splitting at approximately 1095 and $624 \mathrm{~cm}^{-1}$, respectively, as befits uncoordinated anions. ${ }^{28}$ The IR spectra of 1 and 3 exhibit the thiocyanate stretch at around $2040 \mathrm{~cm}^{-1}$. Upon coordination to $\mathrm{Pb}^{\mathrm{II}}$ the $\mathrm{C}=\mathrm{N}$ stretching band of the pyridine moiety in $\mathbf{L}^{7}$ and $\mathbf{L}^{8}$ shifts by $3-15 \mathrm{~cm}^{-1}$ to lower wavenumbers, thereby suggesting that the pyridine nitrogen atom is coordinating to the metal ion in the complexes. The FAB mass spectra, obtained using 3-nitrobenzyl alcohol as the matrix, display intense peaks due to $\left[\mathrm{Pb}\left(\mathbf{L}^{n}-\mathrm{H}\right)\right]^{+}$and $\left[\mathrm{Pb}\left(\mathbf{L}^{n}\right) \mathrm{X}\right]^{+}\left(n=7,8 ; \mathrm{X}=\mathrm{ClO}_{4}^{-}, \mathrm{SCN}^{-}\right)$, which confirms the formation of the desired complexes.

\section{$\underline{\mathrm{X} \text {-ray crystal structures }}$}

The solid-state structures of compounds $\mathbf{L}^{7}, \mathbf{L}^{\mathbf{8}}$, and $\mathbf{1}$ were determined by single-crystal X-ray diffraction analyses. The structures of $\mathbf{L}^{7}$ and $\mathbf{L}^{\mathbf{8}}$ are shown in Figure $\mathbf{1}$ and Figure $\mathbf{2}$, respectively. The bond lengths and angles do not show any significant deviation from the expected values. In both $\mathbf{L}^{7}$ and $\mathbf{L}^{8}$, the tertiary amine nitrogen atoms adopt an endo-endo conformation with their lone pairs pointing inside the macrobicyclic cavity. This conformation is probably imposed by the presence of intramolecular hydrogen-bonding interactions that involve the pivotal nitrogen atoms and $\mathrm{NH}$ groups of the ligand. In the case of $\mathbf{L}^{7}$, the asymmetric unit contains two ligand molecules with only slightly different bond lengths and angles, and therefore we will focus the following discussion on one of these molecules. The secondary amine nitrogen atoms of $\mathbf{L}^{7}$ (N3 and N5) are involved in hydrogen-bonding interactions with the pivotal nitrogen atoms N1

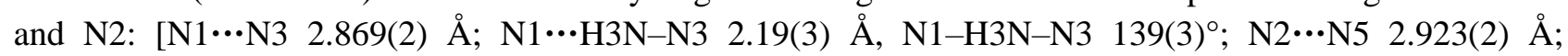
$\mathrm{N} 2 \cdots \mathrm{H} 5 \mathrm{~N}-\mathrm{N} 52.27(3) \AA$, N2-H5N-N5 $\left.135(2)^{\circ}\right]$. The secondary amine groups of $\mathbf{L}^{8}$ are also involved in weak intramolecular hydrogen-bonding interactions: the pivotal nitrogen N5 interacts with N3 [N5 $\cdots \mathrm{N} 3$

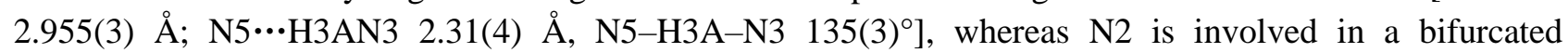


hydrogen-bonding interaction ${ }^{29}$ with $\mathrm{N} 4$ and $\mathrm{O} 4$ [N2 $\cdots \mathrm{N} 42.831(3) \AA$; N2-H2A $\cdots \mathrm{N} 42.12(4) \AA$, N2-H2A$\mathrm{N} 4142(3)^{\circ}$ and $\mathrm{N} 2 \cdots \mathrm{O} 43.320(3) \AA$; N2-H2A $\cdots \mathrm{O} 42.65(4) \AA$, N2-H2A-O4 138(3) ${ }^{\circ}$. The five nitrogen atoms of $\mathbf{L}^{8}$ are essentially coplanar [root-mean-square (rms) deviation from planarity $0.0949 \AA$ ], as well as the four oxygen atoms of the crown moiety (rms deviation from planarity $0.0351 \AA$ ). On the other hand, the different size of the crown moiety fragment in receptors $\mathbf{L}^{7}$ and $\mathbf{L}^{8}$ results in different conformations of the macrobicyclic chain that contain the three aromatic units. Indeed, the angles between the pyridine planes and each benzyl rings amount to 50.4 and $56.4^{\circ}\left(\mathbf{L}^{7}\right)$, and 59.7 and $86.4^{\circ}\left(\mathbf{L}^{8}\right)$, whereas the angles between the least-square planes defined by the benzyl rings are $77.4^{\circ}\left(\mathbf{L}^{7}\right)$ and $38.9^{\circ}\left(\mathbf{L}^{8}\right)$.

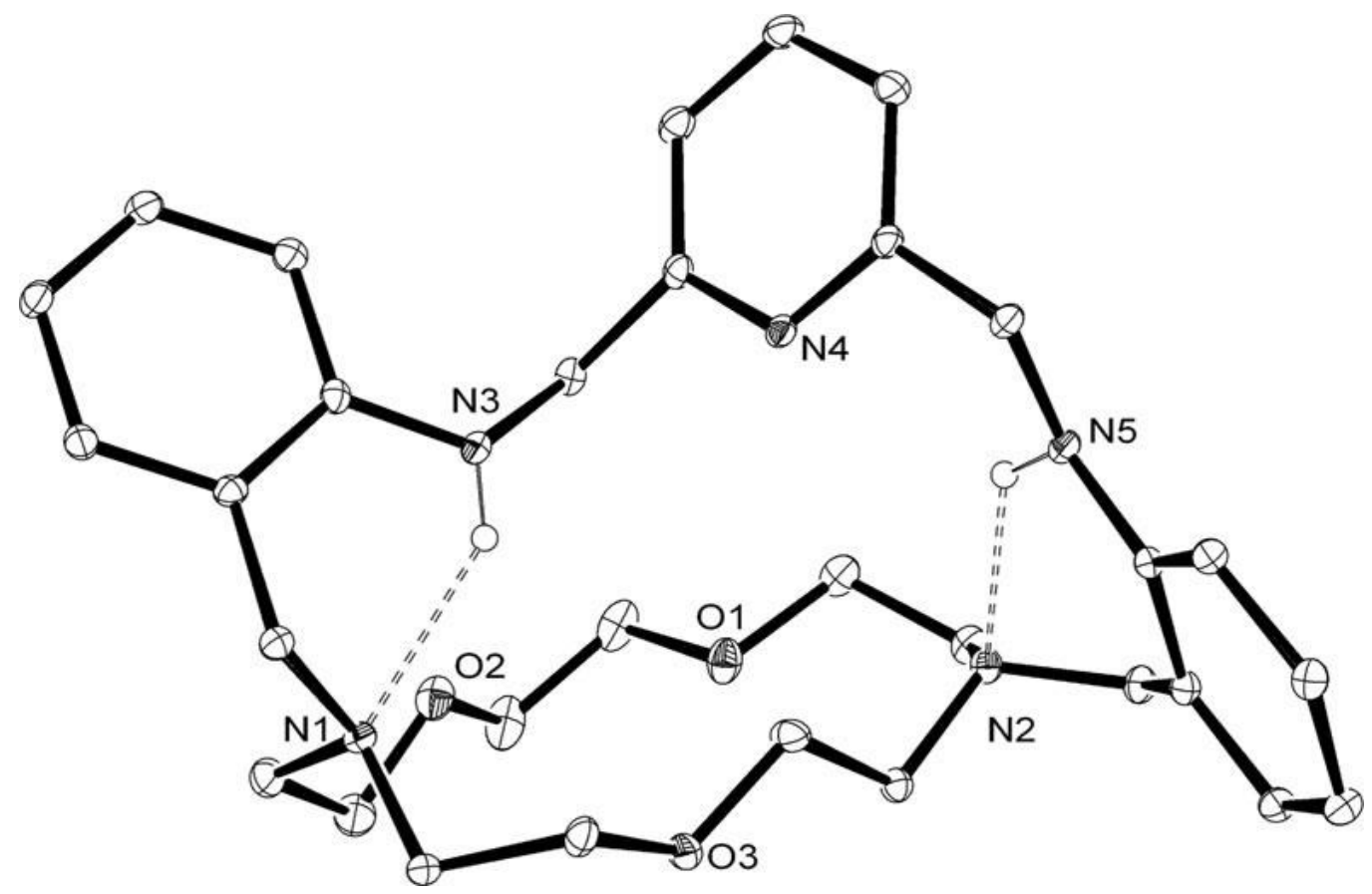

Figure 1. Crystal structure of $\mathbf{L}^{7}$. Only one of the molecules present in the asymmetric unit is shown for the sake of clarity. The ORTEP plot is drawn at the $30 \%$ probability level. Hydrogen atoms, except those involved in intramolecular hydrogen-bonding interactions, are omitted for clarity.

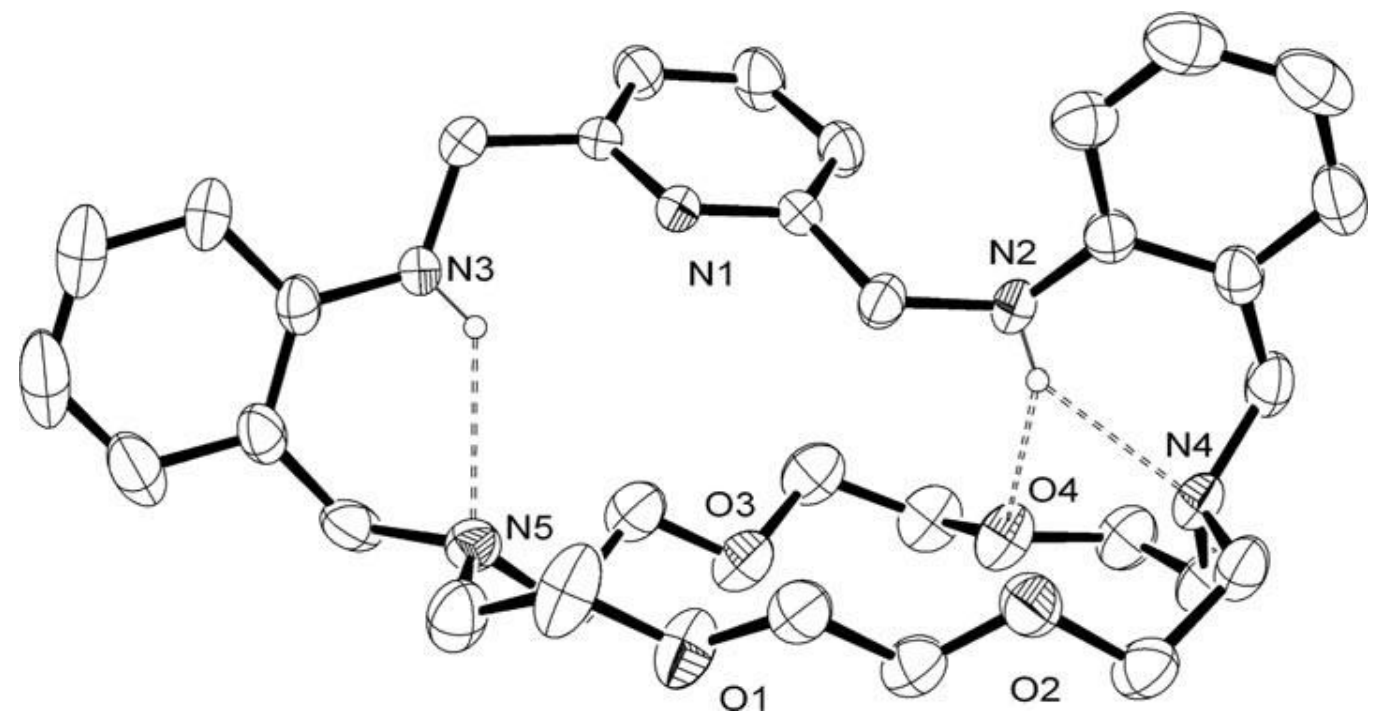

Figure 2. Crystal structure of $\mathbf{L}^{\mathbf{8}}$. The ORTEP plot is drawn at the $30 \%$ probability level. Hydrogen atoms, except those involved in intramolecular hydrogen-bonding interactions, are omitted for clarity. 
Crystals of $\mathbf{1}$ contain the cation $\left[\mathrm{PbL}^{7}(\mathrm{NCS})\right]^{+}$and a noncoordinated thiocyanate anion. Figure $\mathbf{3}$ displays a view of the structure of the cation, whereas selected bond lengths and angles of the metal-coordination environment are given in Table $\mathbf{1}$. The lead(II) ion is asymmetrically placed inside the macrobicyclic cavity. The metal ion is six-coordinate, being bound to the pyridyl nitrogen $\mathrm{N} 3$; both secondary amine nitrogen atoms, $\mathrm{N} 2$ and $\mathrm{N} 4$; two oxygen atoms of the crown moiety, $\mathrm{O} 2$ and $\mathrm{O} 3$; and a nitrogen atom of the coordinated isothiocyanate group (N2S). Both $N^{24,30}$ and $S$-bonded ${ }^{24,31} \mathrm{~Pb}^{\mathrm{II}}$ thiocyanate complexes have been reported in the literature, in line with the classification of this metal ion as intermediate in Pearson's hard and soft (Lewis) acids and bases (HSAB). ${ }^{32}$ The presence of an $N$-bonded $\mathrm{SCN}^{-}$ligand in $\mathbf{1}$ is probably the consequence of the steric hindrance caused around the metal ion by the coordination of the macrobicyclic ligand. ${ }^{33}$ The distances between the lead(II) ion and the two pivotal nitrogen atoms [Pb1-N5 2.939(5) and $\mathrm{Pb} 1-\mathrm{N} 12.990(6) \AA]$ are considerably longer than unequivocal $\mathrm{Pb}-\mathrm{N}$ bonds. The $\mathrm{Pb} 1-\mathrm{O} 1$ distance [2.924(5) $\AA$ ] is also too long to be considered as an unequivocal $\mathrm{Pb}-\mathrm{O}$ bond [the sum of the ionic radius of nonacoordinated $\mathrm{Pb}^{\mathrm{II}},{ }^{34}$ and the van der Waals radii of $\mathrm{N}$ or $\mathrm{O}^{35}$ amount to 2.90 and $2.87 \AA$, respectively]. The secondary amine nitrogen atom $\mathrm{N} 2$ is involved in weak intramolecular hydrogen-bonding interaction

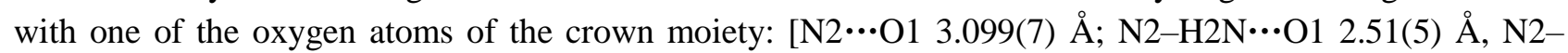
$\left.\mathrm{H} 2 \mathrm{~N}-\mathrm{O} 1{ }_{129}(6)^{\circ}\right]$. This intramolecular hydrogen-bonding interaction may be responsible for the long $\mathrm{Pb} 1-$ $\mathrm{O} 1$ and $\mathrm{Pb} 1-\mathrm{N} 5$ distances observed. Alternatively, these long bond lengths could be attributed to the stereochemical activity of the $\mathrm{Pb}^{\mathrm{II}}$ lone pair, ${ }^{36}$ which causes a nonspherical charge distribution around the $\mathrm{Pb}^{\mathrm{II}}$ cation. However, the lengthening of these bond lengths is expected to be accompanied by a concomitant shortening of the bond lengths to donor atoms placed away from the site of the stereochemically active lone pair. The $\mathrm{Pb} 1-\mathrm{N} 4$ distance $[2.723(5) \AA]$ is not particularly short, and thus we conclude that the $\mathrm{Pb}^{\mathrm{II}}$ lone pair is not stereochemically active in $\mathbf{1}$.

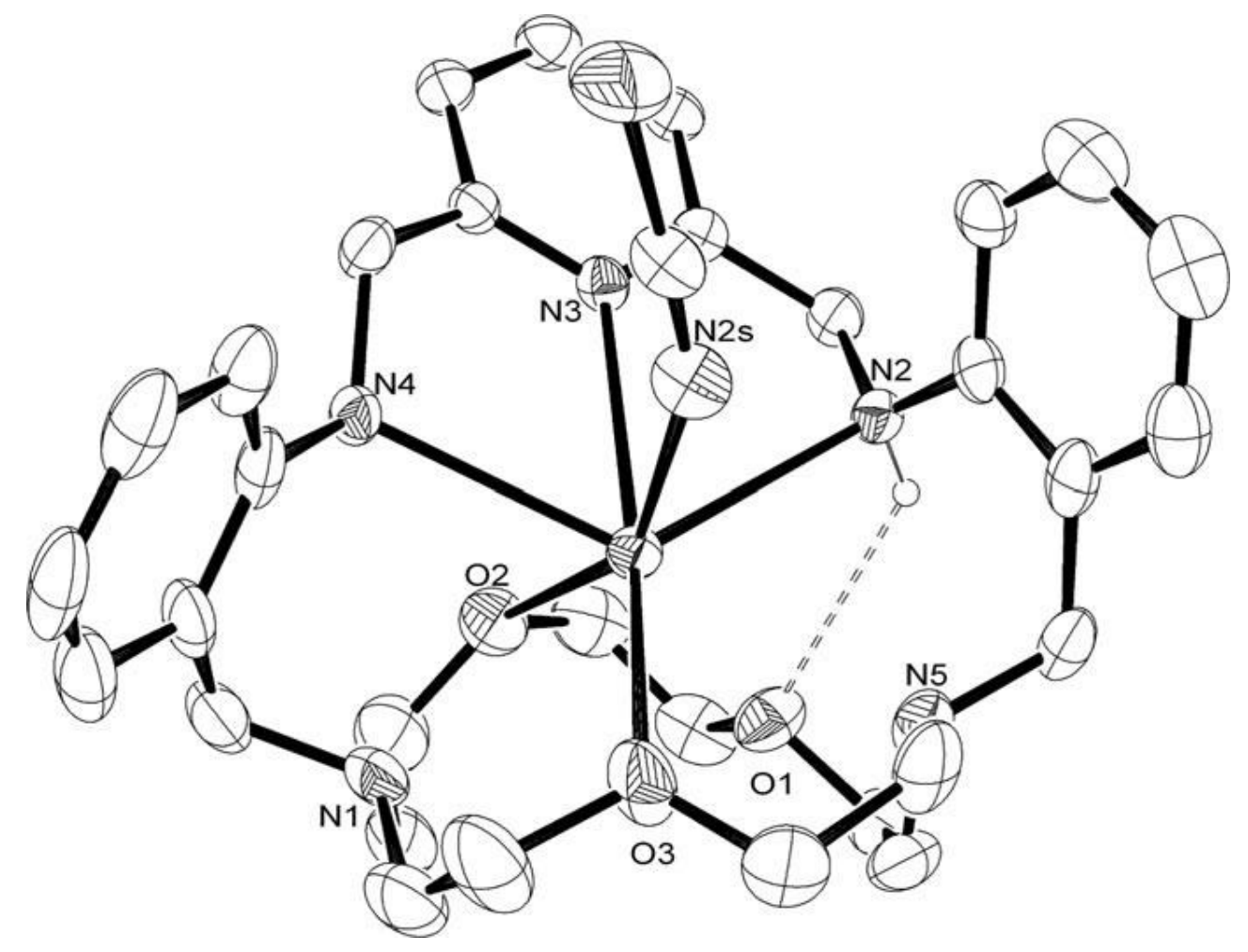

Figure 3. X-ray crystal structure of the cation $\left[\mathrm{PbL}^{7}(\mathrm{NCS})\right]^{+}$in compound $\mathbf{1}$ with atom labeling. Hydrogen atoms, except those involved in intramolecular hydrogen-bonding interactions, are omitted for simplicity. The ORTEP plot is drawn at the $30 \%$ probability level. 
Table 1. Bond lengths $[\AA ̊]$ of the metal-coordination environment in compound 1; see Figure 3 for labeling.

\begin{tabular}{llll}
\hline $\mathrm{Pb} 1-\mathrm{N} 2 \mathrm{~S}$ & $2.450(7)$ & $\mathrm{Pb} 1-\mathrm{O} 2$ & $2.810(5)$ \\
$\mathrm{Pb} 1-\mathrm{N} 3$ & $2.675(5)$ & $\mathrm{Pb} 1-\mathrm{N} 5$ & $2.939(5)$ \\
$\mathrm{Pb} 1-\mathrm{N} 4$ & $2.723(5)$ & $\mathrm{Pb} 1-\mathrm{N} 1$ & $2.990(6)$ \\
$\mathrm{Pb} 1-\mathrm{O} 3$ & $2.686(5)$ & $\mathrm{Pb} 1-\mathrm{O} 1$ & $2.924(5)$ \\
$\mathrm{Pb} 1-\mathrm{N} 2$ & $2.784(6)$ & & \\
\hline
\end{tabular}

The conformation of the macrobicycle in $\mathbf{1}$ is such that the two benzyl rings are folded toward the crown moiety chain that contains $\mathrm{O} 3$, with the angle between the least-square planes defined by the benzyl rings amounting to $67.6(3)^{\circ}$. Angles between the pyridine planes and each of the benzyl rings amount to $68.7(2)$ and 88.6(2) Moreover, the distance between both pivotal nitrogen atoms in $\mathbf{1}$ [4.789(9) $\AA$ ] is much shorter than that found for $\mathbf{L}^{7}$ [6.008(2) $\AA$ ]. Thus, the conformation adopted by the macrobicyclic receptor in $\mathbf{1}$ is considerably different than that observed for uncoordinated $\mathbf{L}^{7}$.

A comparison of the bond lengths of the $\mathrm{Pb}^{\mathrm{II}}$ coordination environment in $\mathbf{1}$ with those observed previously for $\left[\mathrm{Pb}\left(\mathbf{L}^{3}\right)\left(\mathrm{ClO}_{4}\right)\right]^{+[16]}$ shows that the reduction of the imine groups of $\mathbf{L}^{3}$ causes an important lengthening of the distances between the metal ion and donor atoms of the crown moiety $(0.02-0.25 \AA)$. Conversely, the $\mathrm{Pb}-\mathrm{N} 3$ and $\mathrm{Pb}-\mathrm{N} 4$ distances are reduced by approximately 0.03 and $0.11 \AA$. Thus, the reduction of the imine groups of $\mathbf{L}^{3}$ weakens the interaction between the donor atoms of the crown moiety and the metal ion, which in turn strengthens the bonds formed between the $\mathrm{Pb}^{\mathrm{II}}$ and $\mathrm{N}_{3}$ donor set of the macrobicyclic chain that contains the pyridine moiety. We attribute this effect to intramolecular hydrogen-bonding interaction that involves the secondary amine nitrogen atom $\mathrm{N} 2$ and one of the oxygen atoms of the crown moiety in $\left[\mathrm{PbL}^{7}(\mathrm{NCS})\right]^{+}$.

\section{Solution properties}

The formation of the $\mathrm{Pb}^{\mathrm{II}}$ complexes of $\mathbf{L}^{7}$ and $\mathbf{L}^{\mathbf{8}}$ was investigated by using spectrophotometric titrations in acetonitrile. The UV/Vis spectrum of the free receptor $\mathbf{L}^{7}$ recorded in this solvent features two absorption bands with maxima at $252 \mathrm{~nm}\left(\epsilon_{0}=24000 \mathrm{dm}^{3} \mathrm{~mol}^{-1} \mathrm{~cm}^{-1}\right)$ and $291 \mathrm{~nm}\left(\epsilon_{0}=8500 \mathrm{dm}^{3} \mathrm{~mol}^{-1} \mathrm{~cm}^{-1}\right)$, which correspond to $E_{2}$ and $B$ charge-transfer bands of the aromatic rings, respectively. ${ }^{37}$ The spectrum of $\mathbf{L}^{8}$ is nearly identical to that of $\mathbf{L}^{7}$, with bands at $252 \mathrm{~nm}\left(\epsilon_{0}=27000 \mathrm{dm}^{3} \mathrm{~mol}^{-1} \mathrm{~cm}^{-1}\right)$ and $296 \mathrm{~nm}\left(\epsilon_{0}=8100\right.$ $\left.\mathrm{dm}^{3} \mathrm{~mol}^{-1} \mathrm{~cm}^{-1}\right)$. Upon complexation to $\mathrm{Pb}^{\mathrm{II}}$, the absorption that appears at lower energies experiences a blueshift, and the band at $252 \mathrm{~nm}$ splits into two bands at around 240 and $264 \mathrm{~nm}$, thus enabling the formation of the complexes in solution to be monitored (Figure 4). The spectrophotometric titrations of $\mathbf{L}^{7}$ and $\mathbf{L}^{8}\left(1.00 \times 10^{-5} \mathrm{M}\right)$ with $\mathrm{Pb}\left(\mathrm{ClO}_{4}\right)_{2} \cdot 3 \mathrm{H}_{2} \mathrm{O}$ were performed in acetonitrile with $\mathrm{Pb}^{\mathrm{II}} / \mathbf{L}$ molar ratios of $0-4.2$. The data displayed a single inflection point when the $\mathrm{Pb} / \mathbf{L}$ molar ratio is close to 1 for both titrations, thereby indicating the existence of only one complex species in solution with a $1: 1(\mathrm{~Pb} / \mathbf{L})$ stoichiometry. This is confirmed by the presence of isosbestic points at approximately 264 and $285 \mathrm{~nm}$ (Figure 4). These results indicate that both receptors form mononuclear complexes with $\mathrm{Pb}^{\text {II }}$. This is in contrast to the behavior of the Schiff base analogue $\mathbf{L}^{5}$ (Scheme 1), for which spectrophotometric titrations suggested the formation of both $2: 1$ and $1: 1\left(\mathbf{L}^{5} / \mathrm{Pb}\right)$ complexes in solution. ${ }^{15}$ The steep curvature of the titration profiles of $\mathbf{L}^{7}$ and $\mathbf{L}^{8}$ correspond to especially high equilibrium constants. In particular, the $p$ parameter $[p=$ (concentration of the complex)/(maximum possible concentration of the complex)] was found to be higher than 0.8 in both cases, a condition that does not allow the determination of a reliable equilibrium constant. ${ }^{38}$ 


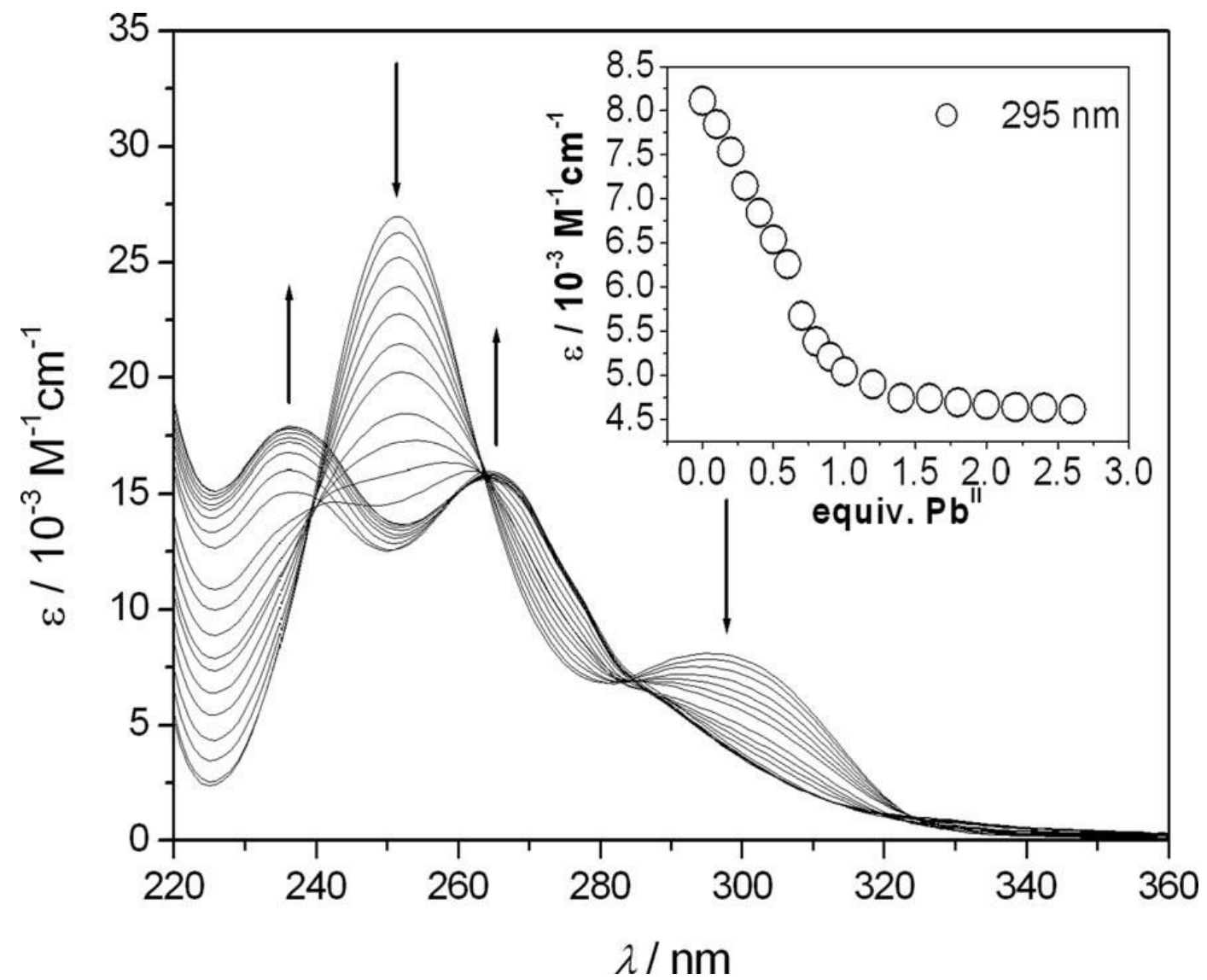

Figure 4. UV/Vis spectrum of $\mathbf{L}^{\mathbf{8}}$ in $\mathrm{CH}_{3} \mathrm{CN}$ and spectral changes upon addition of aliquots of a solution of $\mathrm{Pb}\left(\mathrm{ClO}_{4}\right)_{2} \cdot 3 \mathrm{H}_{2} \mathrm{O}$ in the same solvent. Inset: titration profile at $295 \mathrm{~nm}$.

The behavior of the complexes in $\left[\mathrm{D}_{3}\right]$ acetonitrile was investigated by ${ }^{1} \mathrm{H}$ and ${ }^{13} \mathrm{C}$ NMR spectroscopy. Assignments were achieved with the aid of 2D H,H COSY, heteronuclear multiple quantum coherence (HMQC) and heteronuclear multiple-bond correlation (HMBC) experiments (see Tables S1 and S2 in the Supporting Information). The poor solubility of $\mathbf{1}$ in this solvent prevented us from obtaining NMR spectroscopic data for this compound. The ${ }^{13} \mathrm{C}$ NMR spectrum of compound $\mathbf{2}$ displays 16 signals for the 31 carbon atoms of the ligand backbone, in agreement with an effective $C_{\mathrm{s}}$ symmetry in acetonitrile, whereas the spectra of compounds 3 and $\mathbf{4}$ show $14{ }^{13} \mathrm{C}$ NMR spectroscopic signals (effective $C_{2 v}$ symmetry).

Upon coordination to $\mathrm{Pb}^{\mathrm{II}}$, the signals that correspond to the protons of the pyridine moiety of $\mathbf{L}^{7}, \mathrm{H} 1$ and $\mathrm{H} 2$, shift downfield by 0.39 and $0.23 \mathrm{ppm}$, respectively. A similar behavior is observed for the complexes of $\mathbf{L}^{\mathbf{8}}$. The signals that correspond to the protons of the pyridine moiety, $\mathrm{H} 1$ and $\mathrm{H} 2$, shift downfield by $0.35-$ $0.50 \mathrm{ppm}$ upon coordination (Table S1 in the Supporting Information, Figure 5). These results are indicative of the coordination of the pyridine moiety to $\mathrm{Pb}^{\mathrm{II}}$ in the complexes. The aromatic protons of the benzyl rings (H6-H9) and the methylenic protons H4 and H11 undergo substantial downfield shifts upon coordination to the metal ion. Metal-ion complexation also provokes important shifts of most ${ }^{13} \mathrm{C}$ NMR spectroscopic signals of the three compounds (Table S2 in the Supporting Information). Particularly important shifts upon complexation are observed for $\mathrm{C} 2, \mathrm{C} 5, \mathrm{C} 6, \mathrm{C} 8$, and $\mathrm{C} 10$, in agreement with the coordination to the metal ion of the three nitrogen atoms of the tridentate unit that contains the pyridyl moiety.

The ${ }^{1} \mathrm{H}$ NMR spectrum of $\mathbf{L}^{8}$ shows a broad peak at $\delta=7.59 \mathrm{ppm}$ that is attributable to the $\mathrm{N}-\mathrm{H}$ protons of the secondary amine groups (Figure $\mathbf{5}$ ), whereas for $\mathbf{3}$ and $\mathbf{4}$ this resonance appears at higher fields than in the free ligand ( $\delta=5.68$ and $5.14 \mathrm{ppm}$, respectively). In principle, no distinct region on the $\delta$ scale can be assigned to the resonances of exchangeable protons since the position of these resonance signals is strongly 
dependent upon the medium and temperature. However, it has been suggested that the formation of hydrogen bonds leads to significant shifts to lower fields. ${ }^{39}$ In the case of the $\mathbf{L}^{7}$ complex, metal-ion binding also results in very important shifts to higher fields of the resonance due to $\mathrm{N}-\mathrm{H}$ protons, which points that in both $\mathbf{L}^{7}$ and $\mathbf{L}^{8}$ the secondary amine protons and the pivotal nitrogen atoms are involved in an intramolecular hydrogen-bonding interaction in acetonitrile, as observed in the solid-state structures of the two receptors (vide supra). This hydrogen-bonding interaction is either not present in the complexes or it is weaker than in the free ligands, thereby resulting in important upfield shifts of the signals due to $\mathrm{N}-\mathrm{H}$ protons. A comparison of the ${ }^{1} \mathrm{H}$ NMR spectra recorded for compounds $\mathbf{3}$ and $\mathbf{4}$ shows that the nature of the counterion substantially affects the chemical shifts of the proton nuclei of the ligand (Figure $\mathbf{4}$ and Table S1 in the Supporting Information). Thus, thiocyanate coordination appears to provoke substantial changes in the structure of the complex.

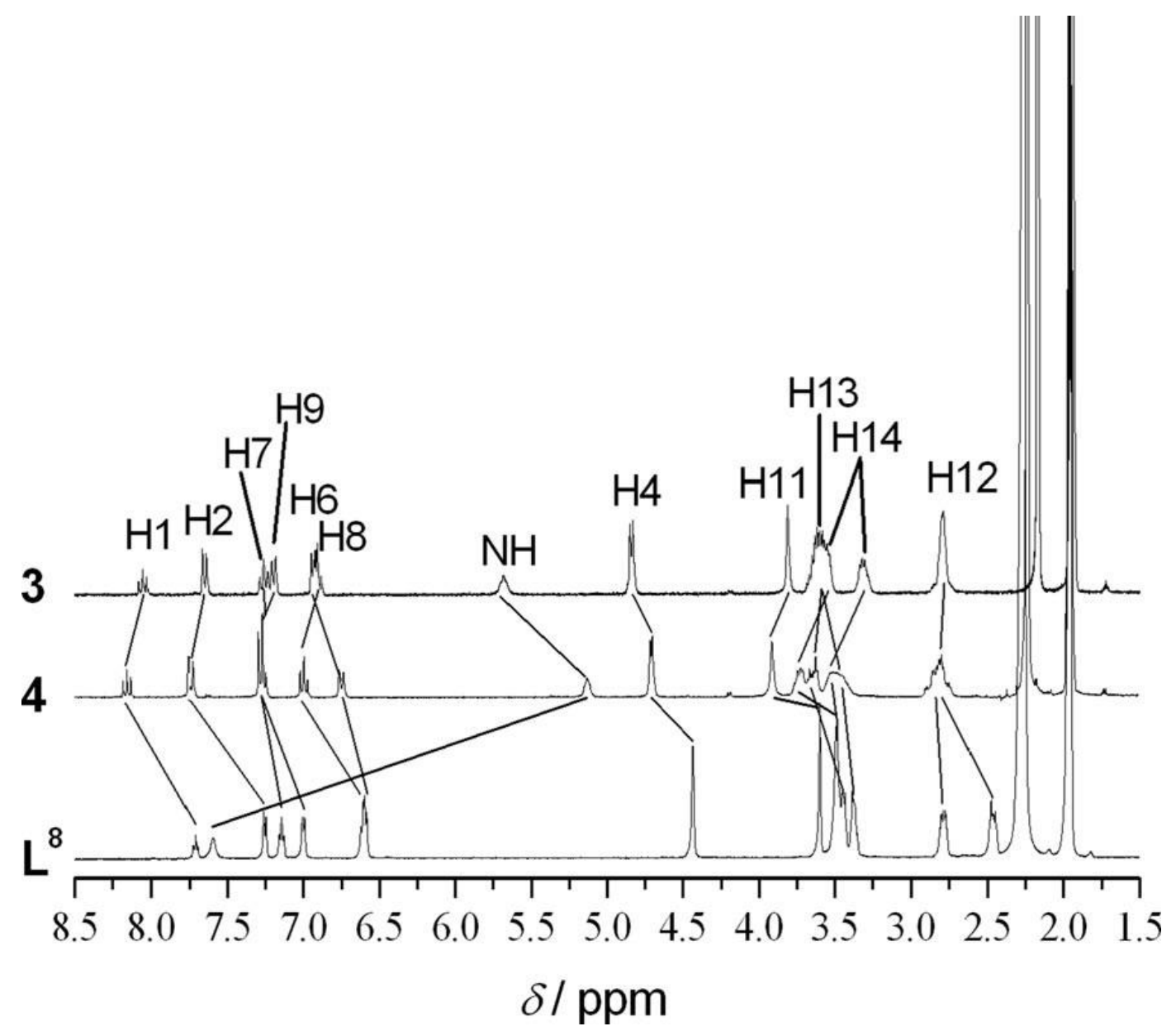

Figure 5. ${ }^{1} \mathrm{H}$ NMR spectra of $\mathbf{L}^{\mathbf{8}}$ and compounds $\mathbf{3}$ and $\mathbf{4}$ recorded in $\mathrm{CD}_{3} \mathrm{CN}$ at $298 \mathrm{~K}$. See Scheme 1 for labeling.

The protonation constants of $\mathbf{L}^{7}$ and $\mathbf{L}^{8}$ as well as the stability constants of their complexes formed with $\mathrm{Pb}^{\mathrm{II}}$ were determined by potentiometric titrations in $95 \%$ methanol; the constants and standard deviations are given in Table 2. For comparative purposes, the protonation constants of $\mathbf{L}^{\mathbf{1}}$ and $\mathbf{L}^{2}$ (Scheme $\mathbf{1}$ ) and the stability constants of their $\mathrm{Pb}^{\mathrm{II}}$ complexes are also reported. All the four ligands undergo two protonation processes in the $\mathrm{pH}$ range investigated $(2.0<\mathrm{pH}<12.0)$, which correspond to the protonation of the nitrogen atoms of the oxa-aza moiety. Protonation of these nitrogen atoms has been observed in the solid-state structure of $\left(\mathrm{H}_{2} \mathbf{L}^{5}\right)\left(\mathrm{ClO}_{4}\right)_{2} \cdot{ }^{40}$ The protonation constants determined for $\mathbf{L}^{\mathbf{2}}$ and $\mathbf{L}^{\mathbf{8}}$ are lower than those 
reported for the parent crown ether 4,13-diaza-[18]crown-6 $\left(\log K_{1}=9.40\right.$ and $\log K_{2}=7.47$ in $95 \%$ methanol, $\left.I=0.1 \mathrm{M} \mathrm{Et}_{4} \mathrm{NClO}_{4}, 25{ }^{\circ} \mathrm{C}\right) .{ }^{41}$ This is in accordance with previous observations in which a diminution of the amine basicity has been observed upon $\mathrm{N}$-alkylation of oxa-aza crown ligands. ${ }^{42}$ Both $\mathbf{L}^{7}$ and $\mathbf{L}^{8}$ show lower protonation constants than the parent receptors $\mathbf{L}^{\mathbf{1}}$ and $\mathbf{L}^{2}$.

Table 2. Ligand protonation constants and stability constants of their metal complexes. ${ }^{[a]}$

\begin{tabular}{lcccc}
\hline & $\mathbf{L}^{\mathbf{1}}$ & $\mathbf{L}^{\mathbf{2}}$ & $\mathbf{L}^{\mathbf{7}}$ & $\mathbf{L}^{\mathbf{8}}$ \\
\hline $\log K_{1}{ }^{[\mathrm{b}]}$ & $7.680(3)$ & $8.025(2)$ & $6.661(7)$ & $6.865(4)$ \\
$\log K_{2}^{[\mathrm{b}]}$ & $6.160(3)$ & $5.591(1)$ & $5.684(6)$ & $5.435(4)$ \\
$\log K_{\mathrm{PbL}}{ }^{[\mathrm{c}]}$ & $8.55(1)$ & $10.63(3)$ & $9.906(1)$ & $8.75(5)$ \\
$\log K_{\mathrm{Pb}(\mathrm{H}) \mathrm{L}}{ }^{[\mathrm{d}]}$ & $4.30(1)$ & $4.01(2)$ & $2.734(3)$ & $3.37(7)$ \\
\hline
\end{tabular}

[a] In $95 \%$ methanol $\left(I=0.1 \mathrm{M}, n \mathrm{Bu}_{4} \mathrm{NClO}_{4}, 25{ }^{\circ} \mathrm{C}\right)$. [b] $\mathrm{H}_{i-1} \mathbf{L}+\mathrm{H}^{+} \leftrightarrows \mathrm{H}_{i} \mathbf{L}, i=1,2$. $[\mathrm{c}] \mathrm{Pb}^{2+}+\mathbf{L} \leftrightarrows[\mathrm{PbL}]^{2+}$. [d] $[\mathrm{Pb} \mathbf{L}]^{2+}+\mathrm{H}^{+} \leftrightarrows[\mathrm{PbHL}]^{3+}$.

The $\log K_{\mathrm{PbL}}$ values reported in Table 2 show that the four ligands investigated form moderately strong complexes with $\mathrm{Pb}^{\mathrm{II}}$. The $\log K_{\mathrm{PbL}}$ value obtained for $\mathbf{L}^{7}$ is approximately $1.4 \log K$ units higher than that determined for the parent receptor $\mathbf{L}^{1}$. However, the $\mathrm{Pb}^{\mathrm{II}}$ complex formed by the macrobicyclic receptor $\mathbf{L}^{8}$ is less stable than that formed with the $\mathbf{L}^{2}$ precursor. This is in line with the solid-state structure of the $\mathrm{Pb}^{\text {II }}$ complex of the macrobicyclic receptor of similar size $\mathbf{L}^{5},{ }^{15}$ which shows that the large macrobicyclic cavity of the receptor does not provide an optimum fit for the complexation of $\mathrm{Pb}^{\mathrm{II}}$. Receptor $\mathbf{L}^{2}$ provides the highest complex stability among the four receptors investigated, in line with the optimum match between the binding sites offered by the ligand and the $\mathrm{Pb}^{\mathrm{II}}$ ion. ${ }^{14}$ All four $\mathrm{Pb}^{\mathrm{II}}$ complexes undergo protonation at low $\mathrm{pH}$ values. This protonation process probably occurs on one of the nitrogen atoms of the aza-crown moiety, as observed in the solid-state structure of the $\left[\mathrm{Pb}\left(\mathrm{HL}^{5}\right)\left(\mathrm{NO}_{3}\right)\right]^{2+}$ complex. ${ }^{15}$

\section{Conclusion}

Lateral macrobicyclic receptors $\mathbf{L}^{7}$ and $\mathbf{L}^{8}$ form moderately strong mononuclear complexes with $\mathrm{Pb}^{\mathrm{II}}$. The stability of these complexes is similar to that observed for the complexes of the parent lariat ethers $\mathbf{L}^{1}$ and $\mathbf{L}^{2}$. The solid-state structure of $\left[\mathrm{Pb}\left(\mathbf{L}^{7}\right)(\mathrm{NCS})\right](\mathrm{SCN}) \cdot 0.5 \mathrm{H}_{2} \mathrm{O}$ shows that the metal ion is coordinated inside the cavity of the macrobicyclic receptor. However, several donor atoms of the macrocycle remain uncoordinated, which is attributed to the relatively large cavity of the receptor and to the presence of a hydrogen-bonding interaction that involves one of thepivotal nitrogen atoms and an $\mathrm{NH}$ group of the receptor. Thus, $\mathrm{N}$-alkylation of these receptors is expected to increase the stability of the corresponding $\mathrm{Pb}^{\mathrm{II}}$ complexes.

\section{Experimental section}

Solvents and starting materials: Receptors $\mathbf{L}^{\mathbf{1}},{ }^{16} \mathbf{L}^{2},{ }^{43} \mathbf{L}^{7},{ }^{27}$ and $\mathbf{L}^{\mathbf{8} 27}$ were prepared as described previously. Single crystals suitable for X-ray crystal diffraction of receptors $\mathbf{L}^{7}$ and $\mathbf{L}^{\mathbf{8}}$ were grown from a solution of the receptor in acetonitrile. All other chemicals were purchased from commercial sources and used without further purification. Solvents were of reagent grade purified by the usual methods, unless otherwise stated. 
Caution! Although we have experienced no difficulties with the perchlorate salts, these should be regarded as potentially explosive and handled with care. ${ }^{44}$

Physical methods: ${ }^{1} \mathrm{H}$ and ${ }^{13} \mathrm{C}$ NMR spectra were carried out with a Bruker Avance $500 \mathrm{MHz}$ spectrometer. Chemical shifts are reported in parts per million ( $\mathrm{ppm}$ ) with respect to TMS. Spectral assignments were based on two-dimensional COSY, HSQC, and HMBC experiments. Elemental analyses were carried out with a Carlo-Erba 1108 elemental analyzer. FAB mass spectra were recorded with a FISONS QUATRO mass spectrometer with $\mathrm{Cs}$ ion gun and 3-nitrobenzyl alcohol as matrix. IR spectra were recorded, as $\mathrm{KBr}$ discs, with a Bruker Vector 22 spectrophotometer. Electronic spectra were recorded at $20{ }^{\circ} \mathrm{C}$ with a PerkinElmer Lambda 900 UV/Vis spectrophotometer using $1.0 \mathrm{~cm}$ quartz cells. Spectrophotometric titrations were performed in the latter spectrometer connected to an external computer. Typically, a $10^{-5} \mathrm{M}$ solution of the ligand $\left(\mathbf{L}^{7}\right.$ or $\left.\mathbf{L}^{8}\right)$ in acetonitrile $(50 \mathrm{~mL})$ was prepared, and then aliquots $(25-300 \mu \mathrm{L})$ of a $10^{-3} \mathbf{M}$ solution of $\mathrm{Pb}\left(\mathrm{ClO}_{4}\right)_{2} \cdot 3 \mathrm{H}_{2} \mathrm{O}$ in the same solvent were successively added. The ionic strength was adjusted to $I=10^{-}$ ${ }^{3} \mathrm{M}$ with tetrabutylammonium perchlorate for each titration.

Potentiometry: Ligand protonation constants and stability constants with $\mathrm{Pb}^{\mathrm{II}}$ were determined at $25{ }^{\circ} \mathrm{C}$ by $\mathrm{pH}$-potentiometric titration in methanol/water mixtures $(95 \% \mathrm{v} / \mathrm{v})$. A correction was made for the small decrease in volume as a consequence of mixing methanol and water. Atmospheric $\mathrm{CO}_{2}$ was excluded from the cell during the titration by constant passage of Ar through the solution. The ionic strength was kept at $0.1 \mathrm{M}$ with tetrabutylammonium perchlorate. The titrations were carried out by adding a standardized tetrabutylammonium hydroxide solution with a Metrohm Dosimat 794 automatic burette. A glass electrode filled with $\mathrm{LiCl}$ in ethanol was used to measure $\mathrm{pH}$. The stock solutions were prepared by dilution of the appropriate standards. The exact amount of acid present in the standard solutions was determined by $\mathrm{pH}$ measurements. Tetrabutylammonium hydroxide was standardized by potentiometric titration against potassium hydrogen phthalate. The ligands were checked for purity by NMR spectroscopy and elemental analysis before titration. The ligand and metal-ligand (1:1) solutions were titrated over the $\mathrm{pH}$ range $2.0<$ $\mathrm{pH}<12.0$. The titration data for $\mathrm{Pb}^{\mathrm{II}}$ complexation were successfully refined assuming the presence of only 1:1 metal-ligand species in solution; in all cases only data that correspond to the lower portions of the titration curves were employed for the calculations in order to avoid complications that arise from competing hydrolysis/precipitation at higher $\mathrm{pH}$ values. The protonation and stability constants were calculated from simultaneous fits of two independent titrations with the program HYPERQUAD. ${ }^{45}$ The errors given correspond to one standard deviation.

$\underline{\text { X-ray crystal structures: }}$ Three-dimensional X-ray data were collected with Bruker X8 APEXII CCD $\left(\mathbf{L}^{7}\right)$ or Bruker SMART 1000 CCD $\left(\mathbf{L}^{\mathbf{8}}, \mathbf{1}\right)$ diffractometers by the $\varphi / \omega$ scan method. Reflections were measured from a hemisphere of data collected of frames, each covering $0.3^{\circ}$ in $\omega$. Of the 52158, 40582, and 41992 reflections measured for $\mathbf{L}^{7}, \mathbf{L}^{\mathbf{8}}$, and $\mathbf{1}$, all of which were corrected for Lorentz and polarization effects and for absorption by semiempirical methods based on symmetry-equivalent and repeated reflections, 6939, 4522, and 3919 independent reflections exceeded the significance level $|F| / \sigma(|F|)>2.0$, respectively. The structures were solved with SHELXS- $97^{46}$ by direct methods and refined by full-matrix least-squares methods on $F^{2}$ (SHELXL-97) ${ }^{46}$ under WINGX. ${ }^{47}$ The hydrogen atoms were included in calculated positions and refined by using a riding mode. Minimum and maximum final electronic density: -0.321 and 0.375 e $\AA^{-}$ ${ }^{3}$ for $\mathbf{L}^{7},-0.170$ and $0.196 \mathrm{e} \AA^{-3}$ for $\mathbf{L}^{8}$, and -1.079 and $2.023 \mathrm{e} \AA^{-3}$ [next to Pb1] for $\mathbf{1}$. Crystal data and details on data collection and refinement are summarized in Table $\mathbf{3}$.

CCDC-779434 (for $\mathbf{L}^{7}$ ), -779435 (for $\mathbf{L}^{\mathbf{8}}$ ), and -779433 (for $\mathbf{1}$ ) contain the supplementary crystallographic data for this paper. These data can be obtained free of charge from The Cambridge Crystallographic Data Centre via www.ccdc.cam.ac.uk/data_request/cif. 
Table 3. Crystal data and structure refinement for compounds $\mathbf{L}^{7}, \mathbf{L}^{\mathbf{8}}$, and $\mathbf{1}$.

\begin{tabular}{llll}
\hline & $\mathbf{L}^{\mathbf{7}}$ & $\mathbf{L}^{\mathbf{8}}$ & $\mathbf{1}$ \\
\hline Formula & $\mathrm{C}_{31} \mathrm{H}_{41} \mathrm{~N}_{5} \mathrm{O}_{3}$ & $\mathrm{C}_{33} \mathrm{H}_{45} \mathrm{~N}_{5} \mathrm{O}_{4}$ & $\mathrm{C}_{33} \mathrm{H}_{41} \mathrm{~N}_{7} \mathrm{O}_{3} \mathrm{PbS}_{2}$ \\
$M_{\mathrm{r}}\left[\mathrm{g} \mathrm{mol}^{-1}\right]$ & 531.69 & 575.74 & 855.04 \\
Crystal system & monoclinic & orthorhombic & orthorhombic \\
Space group & $P 21$ & $P b c a$ & $P b c a$ \\
$T[\mathrm{~K}]$ & $100.0(2)$ & $298.0(2)$ & $298.0(2)$ \\
$a[\AA]$ & $9.7318(4)$ & $22.6248(9)$ & $18.5899(8)$ \\
$b\left[^{\AA} \mathrm{\AA}\right]$ & $11.8580(5)$ & $8.9650(4)$ & $12.9940(6)$ \\
$c[\AA]$ & $24.126(1)$ & $31.2078(1)$ & $28.154(1)$ \\
$\alpha\left[^{\circ}\right]$ & 90 & 90 & 90 \\
$\beta\left[^{\circ}\right]$ & $92.465(3)$ & 90 & 90 \\
$\gamma\left[^{\circ}\right]$ & 90 & 90 & 90 \\
$V\left[^{\circ} \AA^{3}\right]$ & $2781.6(2)$ & $6329.9(4)$ & $6800.8(5)$ \\
$Z$ & 4 & 8 & 8 \\
$\rho_{\text {calcd. }}\left[\mathrm{g} \mathrm{cm}^{-3}\right]$ & 1.270 & 1.208 & 1.670 \\
$\mu\left[\mathrm{mm}^{-1}\right]$ & 0.083 & 0.080 & 5.129 \\
$R_{\text {int }}$ & 0.031 & 0.0556 & 0.0565 \\
$R_{1}{ }^{[\mathrm{a}]}$ & 0.0304 & 0.0802 & 0.0376 \\
$w R_{2}(\mathrm{all} \mathrm{data})^{[\mathrm{b}]}$ & 0.0903 & 0.1819 & 0.1025 \\
\hline
\end{tabular}

[a] $R_{1}=\Sigma|| F_{\mathrm{o}}|-| F_{\mathrm{c}}|| \Sigma\left|F_{\mathrm{o}}\right| .[\mathrm{b}] w R_{2}=\left\{\Sigma\left[w\left(\left.|| F_{\mathrm{o}}\right|^{2}-\left|F_{\mathrm{c}}\right|^{2} \mid\right)^{2}\right] / \Sigma\left[w\left(F_{\mathrm{o}}{ }^{4} \mid\right)\right]\right\}^{1 / 2}$.

$\left[\mathrm{Pb}\left(\mathrm{L}^{7}\right)\right](\mathrm{SCN})_{2}(1): \mathrm{Pb}(\mathrm{SCN})_{2}(0.0231 \mathrm{~g}, 0.071 \mathrm{mmol})$ in absolute ethanol $(5 \mathrm{~mL})$ was added to a solution of $\mathbf{L}^{7}(0.0400 \mathrm{~g}, 0.075 \mathrm{mmol})$ in the same solvent $(10 \mathrm{~mL})$. The resultant solution was heated at reflux with stirring for $2 \mathrm{~h}$ and then allowed to cool. The white precipitate formed was filtered and dried under vacuum over $\mathrm{CaCl}_{2}$ (yield: 0.0550 g, $86 \%$ ). $\mathrm{C}_{31} \mathrm{H}_{41} \mathrm{~N}_{7} \mathrm{O}_{3} \mathrm{PbS}_{2}$ (855.05): calcd. C 46.35, H 4.83, N 11.47, S 7.50; found C 46.58, H 4.43, N 11.77, S 7.83. MS (FAB, 3-nba): $m / z=532\left[\mathbf{L}^{7}+\mathbf{H}\right]^{+}, 739\left[\mathrm{~Pb}\left(\mathbf{L}^{7}-\mathrm{H}\right)\right]^{+}, 797$ $\left[\mathrm{PbL}^{7}(\mathrm{SCN})\right]^{+} . \mathrm{IR}(\mathrm{KBr}): \tilde{\nu}=3369(\mathrm{NH}), 3219,1596[\delta(\mathrm{NH})], 1585\left[v(\mathrm{C}=\mathrm{N})_{\mathrm{py}}, v(\mathrm{SCN})\right] 2049 \mathrm{~cm}^{-1}$. Solution ${ }^{1} \mathrm{H}$ and ${ }^{13} \mathrm{C}$ NMR spectra: Tables S1 and S2 in the Supporting Information. Slow diffusion of diethyl ether into a solution of the complex in methanol/acetonitrile gave crystals of formula $\left[\mathrm{Pb}\left(\mathbf{L}^{7}\right)\right](\mathrm{SCN})_{2} \cdot 0.5 \mathrm{H}_{2} \mathrm{O}$ suitable for X-ray crystallography.

$\left[\mathrm{Pb}\left(\mathrm{L}^{7}\right)\right]\left(\mathrm{ClO}_{4}\right)_{2} \cdot \mathrm{MeOH}(2): \mathrm{Pb}\left(\mathrm{ClO}_{4}\right)_{2} \cdot 3 \mathrm{H}_{2} \mathrm{O}(0.0330 \mathrm{~g}, 0.072 \mathrm{mmol})$ in absolute ethanol $(5 \mathrm{~mL})$ was added to a solution of $\mathbf{L}^{7}(0.0402 \mathrm{~g}, 0.0 .076 \mathrm{mmol})$ in the same solvent $(10 \mathrm{~mL})$. The resultant solution was heated at reflux with stirring for $2 \mathrm{~h}$ and then allowed to cool. The white precipitate formed was filtered and dried under vacuum over $\mathrm{CaCl}_{2}$ (yield: 0.0554 g, $79 \%$ ); m.p. $270{ }^{\circ} \mathrm{C}$ (decomp.). $\mathrm{C}_{32} \mathrm{H}_{45} \mathrm{Cl}_{2} \mathrm{~N}_{5} \mathrm{O}_{12} \mathrm{~Pb}(969.83$ ): calcd. C 39.63, H 4.68, N 7.22; found C 39.31, H 4.80, N 7.05. MS (FAB, 3-nba): $m / z=532\left[\mathbf{L}^{7}+\mathrm{H}\right]^{+}, 739$ $\left[\mathrm{Pb}\left(\mathbf{L}^{7}-\mathrm{H}\right)\right]^{+}, 838\left[\mathrm{PbL}^{7}\left(\mathrm{ClO}_{4}\right)\right]^{+} . \mathrm{IR}(\mathrm{KBr}): \widetilde{\nu}=3479(\mathrm{NH}), 3409,3265,1599[\delta(\mathrm{NH})], 1589\left[v(\mathrm{C}=\mathrm{N})_{\mathrm{py}}\right]$, $1092\left[v_{\mathrm{as}}(\mathrm{Cl}-\mathrm{O})\right] \mathrm{cm}^{-1}$.

$\left[\mathrm{Pb}\left(\mathrm{L}^{8}\right)\right](\mathrm{SCN})_{2} \cdot \mathrm{H}_{2} \mathrm{O}$ (3): The white complex was prepared as described for $\mathbf{1}$ by using $\mathrm{Pb}(\mathrm{SCN})_{2}(0.0160 \mathrm{~g}$, $0.049 \mathrm{mmol}$ ) and $\mathbf{L}^{\mathbf{8}}\left(0.0201 \mathrm{~g}, 0.035 \mathrm{mmol}\right.$ ) (yield: $0.0278 \mathrm{~g}, 87 \%$ ); m.p $222{ }^{\circ} \mathrm{C}$ (decomp.). $\mathrm{C}_{35} \mathrm{H}_{47} \mathrm{~N}_{7} \mathrm{O}_{5} \mathrm{PbS}_{2}$ (917.12): calcd. C 45.84, $\mathrm{H}$ 5.17, $\mathrm{N}$ 10.69; found $\mathrm{C} 46.01, \mathrm{H}$ 4.89, $\mathrm{N}$ 10.55. MS (FAB, $3-$ nba): $m / z=576\left[\mathbf{L}^{8}+\mathrm{H}\right]^{+}, 782\left[\mathrm{~Pb}\left(\mathbf{L}^{8}-\mathrm{H}\right)\right]^{+}, 841\left[\mathrm{PbL}^{8}(\mathrm{SCN})\right]^{+} . \mathrm{IR}(\mathrm{KBr}): \tilde{\nu}=3254(\mathrm{NH}), 1592[\delta(\mathrm{NH})]$, $1579\left[v(\mathrm{C}=\mathrm{N})_{\mathrm{py}}\right], 2040[v(\mathrm{SCN})] \mathrm{cm}^{-1}$. 
$\left[\mathrm{Pb}\left(\mathrm{L}^{8}\right)\right]\left(\mathrm{ClO}_{4}\right)_{2} \cdot \mathrm{H}_{2} \mathrm{O}$ (4): The white complex was prepared as described for $\mathbf{1}$ by using $\mathrm{Pb}\left(\mathrm{ClO}_{4}\right)_{2} \cdot 3 \mathrm{H}_{2} \mathrm{O}$ (0.0160 g, $0.035 \mathrm{mmol}$ )and $\mathbf{L}^{8}$ (0.0201 g, $0.035 \mathrm{mmol}$ ) (yield: $0.0280 \mathrm{~g}, 80 \%$ ). $\mathrm{C}_{33} \mathrm{H}_{47} \mathrm{Cl}_{2} \mathrm{~N}_{5} \mathrm{O}_{13} \mathrm{~Pb}(999.86)$ : calcd. C 39.64, H 4.74, N 7.00; found C 39.80, H 4.66, N 6.83. MS (FAB, 3-nba): $m / z=576\left[\mathbf{L}^{8}+\mathrm{H}\right]^{+}, 782$ $\left[\mathrm{Pb}\left(\mathbf{L}^{8}-\mathrm{H}\right)\right]^{+}, 882\left[\mathrm{PbL}^{8}\left(\mathrm{ClO}_{4}\right)\right]^{+} . \mathrm{IR}(\mathrm{KBr}): \tilde{\nu}=3310(\mathrm{NH}), 1605[\delta(\mathrm{NH})], 1589\left[v(\mathrm{C}=\mathrm{N})_{\mathrm{py}}\right], 1095 \& v_{\mathrm{as}}(\mathrm{Cl}-$ $\mathrm{O}) ; \mathrm{cm}^{-1}$.

\section{Supporting information}

${ }^{1} \mathrm{H}$ and ${ }^{13} \mathrm{C}$ NMR spectral data for $\mathbf{L}^{7}, \mathbf{L}^{8}, \mathbf{2}, \mathbf{3}$ and $\mathbf{4}$. See also the footnote on the last page of this article.

\section{Acknowledgements}

The authors thank Xunta de Galicia (PGIDIT06TAM10301PR and INCITE09E1R103013ES) for generous financial support.

\section{References}

[1] R. M. Harrison, D. R. H. Laxen, in: Lead Pollution, Chapman and Hall, London, 1981.

[2] G. F. Nordberg, BioMetals 2004, 17, 485-489.

[3] R. A. Goyer, in: Handbook on Toxicity of Inorganic Compounds (Eds.: H. G. Seiler, A. Sigel, H. Sigel), Marcel Dekker, New York, 1988, pp. 359-382.

[4] a) H. Sigel, C. P. Da Costa, R. B. Martin, Coord. Chem. Rev. 2001, 219-221, 435-461. b) H. Sigel, B. E. Fischer, E. Farkas, Inorg. Chem. 1983, 22, 925-934. c) H. A. Tajimir-Riahi, M. Langlais, R. Savoie, Nucleic Acids Res. 1988, 16,751-762. d) G. Kazantis, in: Poisoning, Diagnosis and Treatment (Eds.: J. A. Vale, T. J. Meredith), Update Books, London, 1981, pp. 171-175. e) D. Baltrop, in: Poisoning, Diagnosis and Treatment (Eds.: J. A. Vale, T. J. Meredith), Update Books, London, 1981, pp. 178-185.

[5] a) C. P. Da Costa, H. Sigel, Inorg. Chem. 2000, 39, 5985-5993. b) R. B. Martin, Inorg. Chim. Acta 1998, 283, 30-36. c) J. S. Magyar, T.-C. Weng, Ch. M. Stern, D. F. Dye, B. W. Rous, J. C. Payne, M. A. Bridgewater, B. Mijovilovich, G. Parkin, J. M. Zaleski, J. E. Penner-Hahn, H. A. Godwin, J. Am. Chem. Soc. 2005, 127, 9495-9505.

[6] a) B. P. Lanphear, R. Hornung, J. Khoury, K. Yolton, P. Baghurst, D. C. Bellinger, R. L. Canfield, K. N. Dietrich, R. Bornschein, T. Greene, S. J. Rothenberg, H. L. Needleman, L. Schnaas, G. Wasserman, J. Graziano, R. Roberts, Environ. Health Perspectives 2005, 113, 894-899. b) C. Castellino, P. Caselino, N. Sannolo, in: Inorganic Lead Exposure: Metabolism and Intoxication, Lewis, Boca Raton, FL, 1994.

[7] R. T. Daher, Anal. Chem. 1995, 67, 405-410.

[8] a) M. C. Aragoni, M. Arca, A. Bencini, S. Biagini, A. J. Blake, C. Caltaginore, F. Demartin, G. De Filippo, F. A. Devillanova, A. Garau, K. Gloe, F. Isaia, V. Lippolis, B. Valtancoli, M. Wenzel, Inorg. Chem. 2008, 47, 8391-8404. b) P. K. Sazonov, L. K. Minacheva, A. V. Churakov, V. S. Sergienko, G. A. Artamkina, Y. F. Oprunenko, I. P. Beletskaya, Dalton Trans. 2009, 843-850. c) D. Caiazza, S. F. 
Lincoln, A. D. Ward, Inorg. Chim. Acta 2004, 357, 716-722. d) S. H. Hausner, C. A. F. Striley, J. A. Krause-Bauer, H. Zimmer, J. Org. Chem. 2005, 70, 5804-5817. e) W.-S. Xia, R. H. Schmehl, C.-J. Li, J. T. Mague, C.-P. Luo, D. M. Guldi, J. Phys. Chem. B 2002, 106, 833-843. f) R. FerreirosMartinez, D. Esteban-Gomez, A. de Blas, C. Platas-Iglesias, T. Rodriguez-Blas, Inorg. Chem. 2009, 48, 11821-11831. g) R. Ferreiros-Martinez, C. Platas-Iglesias, A. de Blas, D. Esteban-Gomez, T. Rodriguez-Blas, Eur. J. Inorg. Chem. 2010, 2495-2503. h) M. Regueiro-Figueroa, D. EstebanGomez, C. Platas-Iglesias, A. de Blas, T. Rodriguez-Blas, Eur. J. Inorg. Chem. 2007, 2198-2207.

[9] a) R. Metivier, I. Leray, B. Valeur, Chem. Commun. 2003, 996-997. b) N. T. K. Dung, R. Ludwig, New J. Chem. 1999, 23,603-607. c) I. B. Solangi, S. Memon, M. I. Bhanger, Anal. Chim. Acta 2009, 638, 146-153. d) N. M. Buie, V. S. Talanov, R. J. Butcher, G. G. Talanova, Inorg. Chem. 2008, 47, 3549-3558.

[10] a) B. Bag, P. K. Bharadwaj, J. Lumin. 2004, 110, 85-94. b) N. Martin, V. McKee, J. Nelson, Inorg. Chim. Acta 1994, 218, 5-8. c) H.-J. Buschmann, Inorg. Chim. Acta 1985, 98, 43-46. d) J.-M. Lehn, Acc. Chem. Res. 1978, 11, 49-57.

[11] a) D. J. Cram, J. M. Cram, Acc. Chem. Res. 1978, 11, 8-14. b) G. M. Cockrell, G. Zhang, D. G. VanDerveer, R. P. Thummel, R. D. Hancock, J. Am. Chem. Soc. 2008, 130, 1420-1430.

[12] J.-M. Lehn, Pure Appl. Chem. 1980, 52, 2441-2459.

[13] a) C. Platas-Iglesias, D. Esteban, V. Ojea, F. Avecilla, A. de Blas, T. Rodríguez-Blas, Inorg. Chem. 2003, 42, 4299-4307. b) D. Esteban, D. Bañobre, R. Bastida, A. de Blas, A. Macías, A. Rodríguez, T. Rodríguez-Blas, D. E. Fenton, H. Adams, J. Mahía, Inorg. Chem. 1999, 38, 1937-1944. c) F. Avecilla, D. Esteban, C. Platas-Iglesias, A. de Blas, T. Rodríguez-Blas, Acta Crystallogr., Sect. C 2003, 59, m93-m94. d) F. Avecilla, D. Esteban, C. Platas-Iglesias, S. Fernandez-Martinez, A. de Blas, T. Rodríguez-Blas, Acta Crystallogr., Sect. C 2003, 59, m450-m451. e) D. Esteban, C. PlatasIglesias, F. Avecilla, A. de Blas, T. Rodríguez-Blas, Polyhedron 2005, 24, 289-294.

[14] D. Esteban, F. Avecilla, C. Platas-Iglesias, J. Mahía, A. de Blas, T. Rodríguez-Blas, Inorg. Chem. 2002, 41, 4337-4347.

[15] D. Esteban-Gómez, R. Ferreirós, S. Fernández-Martínez, F. Avecilla, C. Platas-Iglesias, A. de Blas, T. Rodríguez-Blas, Inorg. Chem. 2005, 44, 5428-5436.

[16] D. Esteban, D. Bañobre, A. de Blas, T. Rodríguez-Blas, R. Bastida, A. Macías, A. Rodríguez, D. E. Fenton, H. Adams, J. Mahía, Eur. J. Inorg. Chem. 2000, 1445-1456.

[17] M. Thirumavalavan, P. Akilan, M. Kandaswamy, Inorg. Chem. 2003, 42, 3308-3317.

[18] A. Carroy, J.-M. Lehn, J. Chem. Soc., Chem. Commun. 1986, 1232-1234.

[19] S. S. Flack, J.-L. Chaumette, J. D. Kilburn, G. J. Langley, M. Webster, J. Chem. Soc., Chem. Commun. 1993, 399-401.

[20] a) J. M. Mahoney, J. P. Davis, A. M. Beatty, B. D. Smith, J. Org. Chem. 2003, 68, 9819-9820. b) N. Bernier, S. Carvalho, F. Li, R. Delgado, V. Felix, J. Org. Chem. 2009, 74, 4819-4827.

[21] a) J. M. Mahoney, A. M. Beatty, B. D. Smith, J. Am. Chem. Soc. 2001, 123, 5847-5848. b) J. M. Mahoney, K. A. Stucker, H. Jiang, I. Carmichael, N. R. Brickmann, A. M. Beatty, B. C. Noll, B. D. Smith, J. Am. Chem. Soc. 2005, 127, 2922-2928. c) J. M. Mahoney, A. M. Beatty, B. D. Smith, Inorg. 
Chem. 2004, 43, 7617-7621. d) J. M. Mahoney, G. U. Nawaratna, A. M. Beatty, P. J. Duggan, B. D. Smith, Inorg. Chem. 2004, 43, 5902-5907.

[22] a) B. D. Smith, T. N. Lambert, Chem. Commun. 2003, 2261-2268. b) M. J. Deetz, M. Shang, B. D. Smith, J. Am. Chem. Soc. 2000, 122, 6201-6207. c) J. M. Mahoney, R. A. Marshall, A. M. Beatty, B. D. Smith, S. Camiolo, P. A. Gale, J. Supr. Chem. 2001, 1, 289-292. d) A. V. Koulov, J. M. Mahoney, B. D. Smith, Org. Biomol. Chem. 2003, 1, 27-29.

[23] D. Esteban-Gómez, C. Platas-Iglesias, T. Enríquez-Pérez, F. Avecilla, A. de Blas, T. RodríguezBlas, Inorg. Chem. 2006, 45, 5407-5416.

[24] C. Platas-Iglesias, D. Esteban-Gómez, T. Enríquez-Pérez, F. Avecilla, A. de Blas, T. RodríguezBlas, Inorg. Chem. 2005, 44, 2224-2233.

[25] D. Esteban, F. Avecilla, C. Platas-Iglesias, A. de Blas, T. Rodriguez-Blas, Polyhedron 2003, 22, 2709-2717.

[26] D. Esteban-Gómez, C. Platas-Iglesias, F. Avecilla, A. de Blas, T. Rodríguez-Blas, Eur. J. Inorg. Chem. 2007, 1635-1643.

[27] D. Esteban-Gomez, C. Platas-Iglesias, A. de Blas, L. Fabbrizzi, T. Rodriguez-Blas, Chem. Eur. J. 2008, 14, 5829-5838.

[28] K. Nakamoto, in: Infrared and Raman Spectra of Inorganic and Coordination Compounds, 3rd ed., Wiley, New York, Chichester, Brisbane, Toronto, 1972, pp. 142-154.

[29] G. A. Jeffrey, in: Hydrogen Bonding in Biological Structures, Springer-Verlag, Berlin, 1991.

[30] a) A. D. Baranyi, M. Onyszchuk, S. Fortier, J. Chem. Soc., Dalton Trans. 1976, 2301-2305. b) A. Y. Nazarenko, E. B. Rusanov, J. Coord. Chem. 1995, 34, 265-271. c) Y.-Y. Niu, H.-W. Hou, Q.-F. Zhang, X.-Q. Xin, H.-K. Fun, S. Chantrapromma, I. A. Razak, Acta Crystallogr., Sect. C 2001, 57, 526-527. d) J. M. Harrowfield, H. Miyamae, B. W. Skelton, A. A. Soudi, A. H. White, Aust. J. Chem. 1996, 49, 1067-1079.

[31] a) M. G. B. Drew, A. Rodgers, M. McCann, S. M. Nelson, J. Chem. Soc., Chem. Commun. 1978, 415416. b) A. Y. Nazarenko, E. B. Rusanov, Polyhedron 1994, 13, 2549-2553. c) B. Metz, R. Eiss, Acta Crystallogr., Sect. B 1973, 29, 1088-1093.

[32] R. G. Pearson, R. J. Mawby, Halogen Chem. 1967, 3, 55-84.

[33] B. Metz, R. Weiss, Inorg. Chem. 1974, 13, 2094-2098.

[34] R. D. Shannon, Acta Crystallogr., Sect. A 1976, 32, 751-767.

[35] A. Bondi, J. Phys. Chem. 1964, 68, 441-451.

[36] L. Shimoni-Livny, J. P. Glusker, C. W. Bock, Inorg. Chem. 1998, 37, 1853-1867.

[37] R. M. Silverstein, C. Bassler, in: Spectrometric Identification of Organic Compounds, Wiley Interscience, 1967.

[38] a) C. S. Wilcox, in: Frontiers in Supramolecular Chemistry and Photochemistry, VCH, Weinheim, 1991, pp. 123-143. b) L. Vaiana, D. Esteban-Gomez, M. Mato-Iglesias, C. Platas-Iglesias, A. de Blas, T. Rodriguez-Blas, Eur. J. Inorg. Chem. 2009, 400-411. 
[39] H. Günther, in: NMR Spectroscopy, John Wiley \& Sons, Chichester, New York, Brisbane, Toronto, Singapore, 1995.

[40] F. Avecilla, D. Esteban, C. Platas-Iglesias, S. Fernandez-Martinez, A. de Blas, T. Rodriguez-Blas, Acta Crystallogr., Sect. C 2005, 61, o92-o94.

[41] T. W. Hambley, L. F. Lindoy, J. R. Reimers, P. Turner, G. Wei, A. N. Widmer-Cooper, J. Chem. Soc., Dalton Trans. 2001, 614-620.

[42] a) J. R. Price, M. Fainerman-Melnikova, R. R. Fenton, K. Gloe, L. F. Lindoy, T. Rambusch, B. W. Skelton, O. Turner, A. H. White, K. Wichmann, Dalton Trans. 2004, 3715-3726. b) L. F. Lindoy, Pure Appl. Chem. 1997, 69, 2179-2186.

[43] C. Rodriguez-Infante, D. Esteban, F. Avecilla, A. de Blas, T. Rodriguez-Blas, J. Mahia, A. L. Macedo, C. F. G. C. Geraldes, Inorg. Chim. Acta 2001, 317, 190-198.

[44] W. C. Wolsey, J. Chem. Educ. 1973, 50, A335-A337.

[45] P. Gans, A. Sabatini, A. Vacca, Talanta 1996, 43, 1739-1753.

[46] G. M. Sheldrick, Acta Crystallogr., Sect. A 2008, 64, 112-122.

[47] L. J. Farrugia, J. Appl. Crystallogr. 1999, 32, 837-838.

\footnotetext{
${ }^{\mathrm{i}}$ Supporting information for this article is available online: https://doi.org/10.1002/ejic.201000642.
} 